\title{
Developing ESP Supplementary Book Based on Project Based Learning Model For Mechanical Engineering Students
}

\author{
Yuliana Firmanda $^{(1)}$, Widiarini ${ }^{(2)}$, Siti Rofi'ah ${ }^{(3)}$, Istina Atul Makrifah ${ }^{(4)}$ \\ Universitas Nahdlatul Ulama Blitar, Indonesia \\ E-mail: (1)yulianafirmanda10@gmail.com, ${ }^{(2)}$ widiarini@unublitar.ac.id,

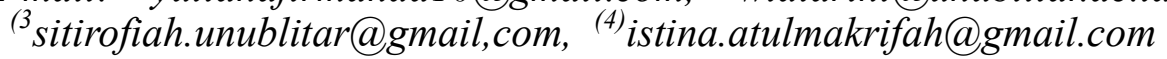

Received: 25 August 2021; Revised: 10 November 2021; Accepted: 13 November 2021

\begin{abstract}
The importance of English in many fields has been faced by many people. Mechanical engineering field is one of the examples. The use of English in mechanical engineering field defined as English for Specific Purposes or ESP. This is proved by preliminary study in this research in which questionnaire and unstructured interview given to 20 students of mechanical engineering study program of UNU Blitar, Principal of Mechanical Engineering Study Program of UNU Blitar and Production Manager of PT. SANMAS DWIKA ABADI shows that it is necessary for mechanical engineering students to master ESP in order to prepare themselves to be good engineers in the future. This paper also aims to investigate the needs of mechanical engineering students of English for Specific Purposes learning materials. This is a Borg \& Gall Research and Development (R\&D) by using questionnaire and unstructured interview instrument. The research subject is 20 fourth semester students of mechanical engineering major in UNU Blitar. The limitation of this study is developing ESP supplementary book based PBL with engineering materials as the topic of the book. The process development of Engineering Materials Supplementary Book Based on ESP and PBL consists of some steps those are (1) Need analysis; (2) Product arrangement; (3) Product testing; and (4) Product revision if it is necessary. This research finds that the supplementary book is valid in three aspects of media $(77.5 \%)$, content $(83.3 \%)$ and language $(83.3 \%)$ and feasible to use as supplement material for the mechanical engineering students. Based on the satisfaction questionnaire this product is appropriate for the mechanical engineering students to learn about English for Specific Purposes in form of Project Based Learning model implementation in percentage about $80 \%$ agree and $15 \%$ very agree.
\end{abstract}

Keywords: English for Specific Purposes (ESP); Project Based Learning (PBL); Supplementary Book; Engineering material; Mechanical engineering.

\section{Introduction}

Unconditionally, industry 4.0 needs English language mastering to reach successful in many fields. In the field of business, mechanical engineering is a field which can not be separated from the importance of English used. Here, engineers which already has international link, needs this language as a global access, for example, $88.1 \%$ of professional company in Indonesia needs engineers which have abilities in mastering English language (Nuryanto, 2017). It will be useful for many things about mechanical engineering, such as finding engineering information whether in online or offline media, look- ing for job or career opportunities or even understanding engineering job description which is commonly written in English language. In addition, regarding to the needs of global market which create big probability for the international or foreign company to come to Indonesia, English language mastering is obviously significant for engineers (Taufan, 2017).

However, acquiring process of English mastery in mechanical engineering field is not easy to do for some people. English language used in mechanical engineering is different and specific, known as English for Specific Purpose (ESP). ESP is defined as the teaching of English 
to the learners who have specific goals and purposes and the goals might be about professional, academic or also scientific (Hutchinson, 2000). In this ESP learning all the materials inside are different, such as the vocabularies, grammatical used and also the meaning are explained in the specific form to the mechanical engineering topics. These differences become the main problem for engineering learners to study English specifically for their needs as engineers

The difficulties of the English language learning in mechanical engineering also experienced by the fourth semester students of mechanical engineering major in Nahdlatul Ulama University of Blitar (UNU Blitar). The students were given questionnaire about the needs of ESP for engineers and 95\% stated that it is hard to learn ESP. However, the students realized that English language mastery is important for their future, especially for helping them to do their job in engineering major. Another supported idea was declared by Principal of Mechanical Engineering Major UNU Blitar. Students in mechanical engineering should have ability about English mastery. In this way, they will need English mastery to do Job Search Skills. Beside, in the field of technique and industry instruction, students will discover function and ability in the English language. Most of instruments in laboratory and workshop use English language, also the identification of the materials and compositions. It means that it is very crucial for engineering students to learn about engineering materials and also the composition as the first introduction in engineering field.

Not only that, according to the result of the questionnaire given to the Production Manager of PT. Sanmas Dwika Abadi, as one of sample for benefit and professional company in Indonesia, the use of English in their company is uncontested. This company always recruits employee who have mastered English language due to most of the working process in this area needs English mastery in writing, listening, speaking and reading, for example, to arrange Certificate of Analysis (COA), Material Safety Data Sheet (MSDS) and Quality Control (QC). Also, working procedure whether in the process of how the machine works or how to operate the engine panel, all of them are written and explained in English language. In addition, the customers who come from other countries require the employee especially for the engineer to have English speaking ability to make the communication process easier.

Dealing with the importance of English in the mechanical engineering field, UNU Blitar already given their students English learning major, but depends on the result from the questionnaire, this English major is delivered as English for general purposes (EGP), not in specific purposes as what mechanical engineering students needs $(95 \%)$. In short, the questionnaire found that $100 \%$ students stated that it is necessary to develop ESP book for them. Based on this result, it can be concluded that it is needed to develop product to solve this problem. In addition, considered to the data gained from Principal of Mechanical Engineering Major UNU Blitar and Production Manager of PT. SANMAS DWIKA AB$\mathrm{ADI}$, the researcher conducted this research by focusing the supplementary book to the topic 'Engineering Materials' due to the first step to learn of ESP in mechanical engineering is about the introduction of the materials itself. Furthermore, this supplementary book developed by implementing Project Based Learning model.

Project Based Learning (PBL) is defined as a learning model where students should building their own content knowledge and demonstrating new understanding through various forms of representation (Moursund, 1999). The effectiveness of the use PBL in engineering students has been found by many researchers. PBL is suitable for engineering students in which this learning model is conducted by 'doing something'. Using Project Based Learning or work by project achieved a deeper development of the students' knowledge and teamwork (Antonio, 2018). Supported by the research in the field of tourism, where it is found that students in tourism schools do need an ESP book specifically for tourism activity that is packaged attractively by applying PBL aim to make them more active in exploring specific English language skill (RIRIN).

At least, there found many research about ESP learning in mechanical engineering field which only focus in the analysis of mechanical engineering students towards ESP. On the other side, this research concern on the development of ESP supplementary book for mechanical engineering students. The supplementary book intends to deliver topic of engineering materials by implementing Project Based Learning. The objectives of this study are to develop English for Specific Purposes (ESP) Supplementary Book Based on Project Based Learning (PBL) model for me- 
chanical engineering students' University of Nahdlatul Ulama Blitar and to find out whether the book is useful for their ESP learning or not.

\section{Materials and Method}

This research adapted research and development model ( $\mathrm{R} \& \mathrm{D})$ developed by Borg and Gall (2003). The steps modified from ten steps into four steps due to the limitation of the time of this research. The step were (1) Need analysis; (2) Product arrangement; (3) Product testing; and (4) Product revision. The data was collected from survey technique by using questionnaire and interview technique by using interview guidelines. Both were utilized in preliminary and final result. Beside, there were three validations in this research and development, (1) language validation of the product; (2) content and media validation of the product; and (3) questionnaire instruments validation. The final data was analyzed and displayed into descriptive quantitative analysis. The data from questionnaire was displayed in form of percentage and described in words as descriptive analysis. In this research, the researcher used eligibility formula by Arikunto to measure whether the product is feasible or not (Arikunto, 2010).

\section{Results and Discussion}

Results Since the objectives of this study are to develop and to find out whether supplementary book is useful for ESP learning or not, so the result consists of two explanations. First is the process of the development and continued by student's satisfaction towards the book. However, it is necessary to present the result from need analysis first.

Need analysis is used to investigate problem and find the solution. Need analysis in this research consists of questionnaire and unstructured interview. Questionnaire and unstructured interview was given to the Principal of Mechanical Engineering Study Program of UNU Blitar as professional lecturer in the field of mechanical engineering subject, Production Manager of PT. Sanmas Dwika Abadi as sample of professional company in Indonesia and 20 students of mechanical engineering of UNU Blitar as the main subject of the research.

Based on the need analysis in the form of unstructured interview and also questionnaire given to engineering students, $95 \%$ of the mechanical engineering students said that it is hard to learn English language, but they realized that English language mastery is important for their future, especially for helping them to do their job in engineering major. Dealing with the importance of English in the mechanical engineering field, UNU Blitar already given their students English learning major, but depends on the result from the questionnaire, this English major is delivered as English for general purposes (EGP), not in specific purposes as what mechanical engineering students needs (95\%). In short, the questionnaire found that $100 \%$ students agreed that it is necessary to develop ESP book for them.

In addition, Principal of Mechanical Engineering Major UNU Blitar explained that students in mechanical engineering should have ability about English mastery. In this way, they will need English mastery to do Job Search Skills. Beside, in the field of technique and industry instruction, students will discover function and ability in the English language. Most of instruments in laboratory and workshop use English language, also with the identification of the materials and compositions.

Production Manager of PT. SANMAS DWIKA ABADI was also stated that the use of English in their company is uncontested. This company always recruits employee who have mastered English language due to most of the working process in this area needs English mastery in writing, listening, speaking and reading, for example, to arrange Certificate of Analysis (COA), Material Safety Data Sheet (MSDS) and Quality Control (QC). Also, working procedure whether in the process of how the machine works or how to operate the engine panel, all of them are written and explained in English language. In addition, the customers who come from other countries require the employee especially for the engineer to have English speaking ability to make the communication process easier. Based on the need analysis result above, it was concluded that the development of ESP supplementary book for mechanical engineering students was necessary.

Net, there found three process of development, those were (1) product arrangement; (2) product testing; and (3) product revision. Considered to the data gained from questionnaire and unstructured interview this research found that it is necessary to develop supplementary book for mechanical engineering students aims to help them in learning English for Specific Purposes. This research conducted by focusing the supplementary book to the topics 'Engineering 
Materials' due to the first step to learn of ESP in mechanical engineering is about the introduction of the materials itself. Furthermore, this supplementary book developed by implementing Project Based Learning model which is potentially implemented well in the mechanical students as learners by practice.

The product arrangement started by creating supplementary book outline, in which mentioned only the main sub-materials of the book without explanation. The outline arrangement is taken from many sources, such engineering books, article journals and also website. This outline was consulted to the expert of content validity before developed into full and completed supplementary book. The completed supplementary book then given to the some experts to get product validity. There were three validation product, those were media validation, content validation and language validation.

This supplementary book is having validity level VALID in the three aspects mentioned above, which means the product is feasible to use by the students. This validity process was aimed to get feasibility of the product before it distributed to the mechanical engineering students. The validity process was using closed questionnaire and analyzed by validity formula from Arikunto.

Bellow is the formula to analyzed the product validy (Arikunto, 2010):

$$
\mathrm{P} \quad=\frac{\sum x}{\sum x i} \times 100 \%
$$

$\begin{array}{ll}\mathrm{P} & =\text { Eligibility } \\ \sum \mathrm{x} & =\text { Number of assessment answer } \\ \sum \mathrm{xi} & =\text { Highest number of answer }\end{array}$

Table 1 is the validity of the product. Language validity and content validity were having validation at the percentage of $83.3 \%$, which means that the supplementary book can be said as valid. In the media validation, this supplementary book was getting percentage of $77.5 \%$ which means that the supplementary book can be said as feasible. Table 2 is content expert validation results

However, there found some comments or suggestions from the expert about the product. The comments outlined the layout of the book, such as changing the pictures used, adding year of the book and correcting some error
Table 1. Language expert validation results

\begin{tabular}{|l|c|l|}
\hline \multicolumn{1}{|c|}{ Butir Penilaian } & Persen & Kriteria \\
\hline Ketepatan struktur kalimat & $75 \%$ & Valid \\
\hline Keefektifan kalimat & $75 \%$ & Valid \\
\hline Kebakuan istilah & $75 \%$ & Valid \\
\hline Kejelasan instruksi & $100 \%$ & Very valid \\
\hline Keruntutan kalimat & $75 \%$ & Valid \\
\hline $\begin{array}{l}\text { Pemahaman terhadap pesan } \\
\text { atau informasi }\end{array}$ & $100 \%$ & Very valid \\
\hline $\begin{array}{l}\text { Kemampuan memotivasi } \\
\text { peserta didik }\end{array}$ & $75 \%$ & Valid \\
\hline $\begin{array}{l}\text { Ketepatan tata bahasa } \\
\text { Ketepatan ejaan }\end{array}$ & $75 \%$ & Valid \\
\hline
\end{tabular}

Table 2. Content expert validation results

\begin{tabular}{|l|c|c|}
\hline \multicolumn{1}{|c|}{ Butir Penilaian } & Persen & Kriteria \\
\hline Keakuratan konsep & $75 \%$ & Valid \\
\hline Keakuratan data dan fakta & $75 \%$ & Valid \\
\hline $\begin{array}{l}\text { Keakuratan contoh dan tugas } \\
\text { proyek yang diberikan kepada } \\
\text { mahasiswa teknik mesin }\end{array}$ & $75 \%$ & Valid \\
\hline $\begin{array}{l}\text { Keakuratan gambar dan } \\
\text { ilustrasi }\end{array}$ & $100 \%$ & $\begin{array}{l}\text { Sangat } \\
\text { valid }\end{array}$ \\
\hline Keakuratan istilah-istilah & $75 \%$ & Valid \\
\hline $\begin{array}{l}\text { Gambar dan ilustrasi sesuai } \\
\text { dengan kebutuhan mahasiswa } \\
\text { teknik mesin }\end{array}$ & $75 \%$ & Valid \\
\hline $\begin{array}{l}\text { Menggunakan contoh, soal dan } \\
\text { proyek yang sesuai dengan } \\
\text { kebutuhan mahasiswa teknik } \\
\text { mesin }\end{array}$ & $75 \%$ & Valid \\
\hline $\begin{array}{l}\text { Mendorong rasa ingin tahu } \\
\text { Mendorong proses menggali } \\
\text { informasi }\end{array}$ & $75 \%$ & Valid \\
\hline
\end{tabular}

typing. The suggestions were completely finished before the product is tested to the research subject to gain product satisfaction questionnaire.

Product testing in this research conducted by giving presentation about the product to the mechanical engineering students. The presentation aimed to show them how to use the supplementary book to help them in learning ESP including explanation about Project Based Learning implementation inside. The students were also given 30 minutes to read and understand the book. In the last, they were asked to fill the product satisfaction questionnaire in order to find out whether the product is feasible for them or not.

Product revision was the last step of this product development process. This revision 
Journal Of Development Research, 5 (2), November 2021, 186-192

Table 3. Media expert validation results

\begin{tabular}{|c|c|c|}
\hline Butir Penilaian & Persen & $\begin{array}{l}\text { Krite- } \\
\text { ria }\end{array}$ \\
\hline $\begin{array}{l}\text { Kesesuaian ukuran buku dengan } \\
\text { kebutuhan mahasiswa teknik me- } \\
\text { sin }\end{array}$ & $75 \%$ & Valid \\
\hline $\begin{array}{l}\text { Kesesuaian ukuran buku dengan } \\
\text { materi isi }\end{array}$ & $75 \%$ & Valid \\
\hline $\begin{array}{l}\text { Penampilan unsur tata letak pada } \\
\text { sampul depan, belakang dan } \\
\text { punggung secara konsisten dan } \\
\text { berkesesuaian }\end{array}$ & $75 \%$ & $\overline{\text { Valid }}$ \\
\hline $\begin{array}{l}\text { Warna unsur tata letak yang } \\
\text { memperjelas fungsi }\end{array}$ & $75 \%$ & Valid \\
\hline $\begin{array}{l}\text { Huruf yang digunakan menarik } \\
\text { dan mudah untuk dibaca }\end{array}$ & $75 \%$ & Valid \\
\hline Ukuran huruf proporsional & $75 \%$ & Valid \\
\hline $\begin{array}{l}\text { Warna judul buku suplemen } \\
\text { kontras dengan warna latar } \\
\text { belakang }\end{array}$ & $75 \%$ & Valid \\
\hline $\begin{array}{lcc}\text { Tidak } & \text { menggunakan } & \text { terlalu } \\
\text { banyak kombinasi huruf } & \end{array}$ & $100 \%$ & $\begin{array}{l}\text { Sangat } \\
\text { valid }\end{array}$ \\
\hline $\begin{array}{l}\text { Ilustrasi sampul buku suplemen } \\
\text { sesuai dengan tema atau isi } \\
\text { materi }\end{array}$ & $75 \%$ & Valid \\
\hline Tata letak konsisten & $75 \%$ & Valid \\
\hline Pemisah antar paragrah jelas & $75 \%$ & Valid \\
\hline $\begin{array}{l}\text { Bidang cetak dan margin } \\
\text { proporsional }\end{array}$ & $75 \%$ & Valid \\
\hline $\begin{array}{l}\text { Spasi antar teks dan ilustrasi } \\
\text { sesuai }\end{array}$ & $75 \%$ & Valid \\
\hline $\begin{array}{l}\text { Unsur tata letak yang meliputi } \\
\text { judul, sub-judul dan angka } \\
\text { halaman lengkap }\end{array}$ & $75 \%$ & Valid \\
\hline $\begin{array}{l}\text { Tidak menggunakan terlalu } \\
\text { banyak jenis huruf }\end{array}$ & $75 \%$ & Valid \\
\hline $\begin{array}{l}\text { Penggunaan variasi huruf (bold, } \\
\text { italic, all capital) tidak } \\
\text { berlebihan }\end{array}$ & $75 \%$ & Valid \\
\hline Lebar susunan teks normal & $75 \%$ & Valid \\
\hline $\begin{array}{l}\text { Spasi antar baris susunan teks } \\
\text { normal }\end{array}$ & $75 \%$ & Valid \\
\hline Spasi antar huruf normal & $75 \%$ & Valid \\
\hline $\begin{array}{l}\text { Ilustrasi isi mampu menjelaskan } \\
\text { makna dari objek }\end{array}$ & $100 \%$ & $\begin{array}{l}\text { Sangat } \\
\text { valid }\end{array}$ \\
\hline
\end{tabular}

should be referred to the product satisfaction questionnaire that is given to the research subject, but in this research the result of the product satisfaction is feasible for the mechanical engineering students. So, there is no more product revision needed or in other words, the "Engineering Materials Supplementary Book based on ESP and PBL" is com-
Table 4. Students' satisfaction

\begin{tabular}{|l|c|}
\hline \multicolumn{1}{|c|}{ Pernyataan } & $\begin{array}{c}\text { Kepua- } \\
\text { san (\%) }\end{array}$ \\
\hline Tampilan buku menarik & $95 \%$ \\
\hline $\begin{array}{l}\text { Buku dapat meningkatkan semangat } \\
\text { belajar terhadap ESP }\end{array}$ & $90 \%$ \\
\hline $\begin{array}{l}\text { Buku dapat membantu siswa untuk } \\
\text { belajar bahasa Inggris dengan } \\
\text { bantuan media }\end{array}$ & $90 \%$ \\
\hline $\begin{array}{l}\text { Buku dapat membuat siswa menjadi } \\
\text { lebih aktif dalam menggali informasi } \\
\text { dan data }\end{array}$ & $90 \%$ \\
\hline $\begin{array}{l}\text { Ilustrasi atau gambar memudahkan } \\
\text { untuk memahami isi atau materi }\end{array}$ & $90 \%$ \\
\hline $\begin{array}{l}\text { Materi dalam buku sesuai dengan } \\
\text { kebutuhan mahasiswa teknik mesin }\end{array}$ & $90 \%$ \\
\hline $\begin{array}{l}\text { Penyajian isi materi dengan soal } \\
\text { berbentuk proyek membantu siswa } \\
\text { untuk lebih aktif dalam belajar }\end{array}$ & $95 \%$ \\
\hline $\begin{array}{l}\text { Materi yang disajikan sudah runtut } \\
\text { dan mudah dipahami }\end{array}$ & $95 \%$ \\
\hline $\begin{array}{l}\text { Buku dapat mendorong siswa untuk } \\
\text { berfikir kreatif dan responsif }\end{array}$ & $95 \%$ \\
\hline \begin{tabular}{l} 
Kalimat dalam buku mudah dipahami \\
\hline $\begin{array}{l}\text { Bahasa yang digunakan sederhana } \\
\text { dan mudah dipahami tidak berbasa- } \\
\text { basi) }\end{array}$
\end{tabular} \\
\hline $\begin{array}{l}\text { Pemilihan huruf dan layout } \\
\text { memudahkan untuk membaca dan } \\
\text { memahami isi buku }\end{array}$ \\
\hline
\end{tabular}

plete and ready to use as supplement source in learning ESP.

Second, to find out the use of this supplementary book, the next step of the development process is giving satisfaction questionnaire to the research subjects. The percentage of the questionnaire result shown in Table 4.

The first aspect discussed in the questionnaire was about the layout of the supplementary book. Based on the table above, it can be seen that more than $80 \%$ students said that the supplementary book layout is attractive. It is supported by the next statements which describes that the illustration and layout including color, font and size of the book is useful for them to make the learning process easier. In conclusion, dealing with the result of media validity in which this supplementary book is feasible on $77.5 \%$ valid, so it is acceptable that the layout of this book is appropriate to the mechanical engineering students needs in learning ESP. In short, the layout or the media aspect of this product is feasible to use.

The second aspect is about the content of the supplementary book. This aspect focused on the use of ESP language and also the PBL 
implementation. From the questionnaire result above, $90 \%$ of the students stated that the content or material of the book is suitable to the needs of the mechanical engineering students. In other words, the ESP learning in the book is implemented well. It is supported by the statement that the product helped the mechanical engineering students to learn about ESP in form of engineering materials topic $(90 \%)$. In addition, $90 \%$ of the students said that the material of the supplementary book is presented as coherent and easy to understand, involves the grammatical rules, vocabularies, tenses, sentences and the language is simple and understandable for mechanical engineering students in the ESP roles. The material of the book in which presented in form of link to the learning video is also useful for the learners to learn about ESP. The video helped the students to learn about listening and also speaking skill. This result is appropriate to the result of the previous study in which found that it is important for mechanical engineering students to learn about ESP in form of listening, speaking, reading, writing, pronunciation, grammar, vocabularies materials (Meiristiani and Ekawati, 2018). In conclusion, the ESP content of this supplementary book is feasible.

Besides the ESP aspect, this supplementary book is also implementing Project Based Learning model as the task inside. From the table above, $90 \%$ of the students agreed that PBL presentation in form of project tasks or learning by doing project helps them to be more active in finding information about engineering materials. The PBL task implementation is also helping the students to think creatively and responsively. This result is appropriated to the content validity result where the validity level was on $83.3 \%$ or feasible or valid. The feasibility of PBL implementation in this product involves the accuracy of sample and project task in which using examples, questions and projects that is appropriate to the engineering student's needs as ESP learners $(83.3 \%)$.

Not only that, there also found previous study in which stated that using Project Based Learning or work by project achieved a deeper development of the students' knowledge in mechanical engineering students in the university level (Antonio, 2018). Considered to this previous study result, implementing PBL task in this supplementary book in which getting data that the students were obviously accept this model is acceptable. In addition, the previous study was focused to the university level as same as this research. In short, it can be concluded that PBL implementation in this product is feasible for mechanical engineering students in the university level.

\section{Conclusion}

The process development of Engineering Materials Supplementary Book Based on ESP and PBL consists of some steps adapted form Borg and Gall theory, including (1) Need analysis process by using questionnaire and unstructured interview to gather the data, (2) Product arrangement started from creating supplementary book outline until completed book based on the data from need analysis including product validity process; (3) Product testing by giving classroom presentation product and satisfaction questionnaire to the research subjects; and (4) Product revision if it is necessary, but in this research there was no revision after the product testing due to the result of the testing was feasible. The step was appropriate to be referenced in the developing materials for ESP learning.

Supported by the result of this research, showed that the supplementary book is valid in three aspects of media $(77.5 \%)$, content $(83.3 \%)$ and language $(83.3 \%)$ and feasible to use as supplement material for the mechanical engineering students. It is supported by the satisfaction questionnaire in which this product is appropriate for the mechanical engineering students to learn about English for Specific Purposes in form of Project Based Learning model implementation in percentage about $80 \%$ to $90 \%$. In short, this supplementary book is feasible to use as supplement material for mechanical engineering students.

\section{References}

Anthony, L. (2007). The Teacher as Student in ESP Course Design. International Symposium on ESP Journal , 1-2.

Antonio, Edilberto. (2018). Project Based Learning Case of Study Education in Automotive Mechanical Engineering. Espacios Journal. 39(10).

Arikunto, S. (2010). Prosedur Penelitian Suatu Pendekatan Praktik. Jakarta: PT. Rineka Cipta.

Ary, Donald et all. 2010. Introduction to Research in Education. USA: Words Woth

Borg, W.R \& Gall, M.D. (2003). Educational Research: an Introduction (7.ed). New York: Longman Inc 
Graves, K. (2000). Designing Language Courses: A Guide for Teachera. Boston: Heinle \& Heinle Publishers

Holubova, R. (2008). Effective Teaching Methods - Project-Based Learning in Physics. USChina Education Review, 12(5), 27-35.

Huchinson, T. \& Waters, A. (1987). English for Specific Purposes. Cambridge: Cambridge University Press.

Javid, C.Z. (2015). English for Specific Purposes: Role of Learners, Teachers and Teaching Methodologies. European Scientific Journal. 11(20).

McGrath, I. (2013). Teaching Materials and the Roles of EFL/ESL Teachers: Practice and Theory. India: Bloomsbury Publishing Plc.

Meiristiani, Noeris \& Ekawati, Yulia. (2018). Need Analysis of the Mechanical Engineering Students in Learning English For Specific Purposes.RILL Journals. 1(3).

Mergendoller, J.R. \& Thomas, J.W. (2005). Managing Project Based Learning: Principles From the Field. California: Buck Institute for Education.

Moleong, Lexi. (2002). Metodologi Penelitian Kualitatif. Bandung: PT Remaja Sodakarya.

Moursund, D. (1999). Project-Based Learning Using Information Technology. Turkey: Eugeme, ISTE International Society for Technology in Education.

Muniandy, B. (2000). An Investigation of the Use of Constructivism and Technology in Project-Based Learning. Unpublished doctoral dissertation, University of Oregon. Fakultas Teknik Universitas Negeri Yogyakarta.

Narayan, Rup. (2016). Importance of English in Engineering for Professional Communication: A Study in the Nepalase Context. Journal of the institute of Engineering. 12(1). 222-227.

Nuryanto, Apri. (2017). Analisis Peluang Kerja Bidang Teknik Mesin Pada Bursa Kerja Online. Hutchinson, T. (2000). English for Specific Purposes: A learning-centred approach. New York: Cambridge University Press.

Richards, J. C. \& Schmidt, R. (2010). Longman Dictionary of Language Teaching and Applied Linguisticts. Harlow: Pearson Education Limited.

Sugiyono. 2008. Metode Penelitian Kualitatif dan $R \& D$. Bandung: ALFABETA
Taufan, Angga. (2017). Pengembangan Materi Ajar Bahasa Inggris Teknik Mesin Universitas Islam Kalimantan MAB. Prosiding Hasil Penelitian Dosen Uniska Tahun 2017.

Tomlinson, B. (1998). Materials Development in Language Teaching. Cambridge: Cambridge University Press.

Waloyo, Alimin A. (2019). Analyzing ESP Learner's Needs at University of Muhammadiyah Malang for a Quality ESP Book. Jurnal Pascasarjana IAIN Mataram.8(1).(51-60)

Wurdinger, S., Haar, J., Hugg, R., \&Bezon, J. (2007). A Qualitative Study Using Project-Based Learning in a Mainstream Middle School. Improving Schools, 10 (2), 150-161

Yosar. (2019). Penerapan Model Project Based Learning Untuk Meningkatkan Hasil Belajar Peserta Didik Pada Mata Pelajaran Teknik Pemesinan Kelas XI Jurusan Teknik Mesin SMK Negeri 5 Makasar. E-Prints Journals. 